\title{
Тютюнокуріння: розповсюдженість та вплив на органи і тканини порожнини рота (огляд літератури)
}

Резюме. Тютюнокуріння є глобальною проблемою людства, а його вплив на стан органів і тканин порожнини рота є великою медико-соціальною проблемою. 3 курінням пов'язують істотне підвищення ризику ряду захворювань порожнини рота, перш за все патології парадонта та онкологічних новоутворень. До групи ризику виникнення раку порожнини рота належать особи, які мають великий стаж куріння, використовують тютюнові продукти для перорального застосування, крім куріння, зловживають алкоголем. Тяжкість захворювань пародонта прямо залежить від віку початку куріння, його тривалості та кількості цигарок, які викурюються щодня. У літературних джерелах багато робіт присвячено дослідженню впливу куріння на стан пародонта. Однак ряд аспектів, зокрема стан вільнорадикального окиснення, залишений без належної уваги, що і буде метою наших подальших досліджень.

Ключові слова: тютюнокуріння, порожнина рота.

\section{В. В. Щерба, О. Я. Лаврин}

ГВУЗ «Тернопольский государственный медицинский университет имени И. Я. Горбачевского»

\section{Курение: распространенность и влияние на органы и ткани полости рта (обзор литературы)}

Резюме. Курение является глобальной проблемой человечества, а его влияние на состояние органов и тканей полости рта является большой медико-социальной проблемой. С курением связывают существенное повышение риска ряда заболеваний полости рта, прежде всего патологии пародонта и онкологических новообразований. В группу риска возникновения рака полости рта относятся лица, имеющие большой стаж курения, используют табачные продукты для перорального применения, кроме курения злоупотребляют алкоголем. Тяжесть заболеваний пародонта напрямую зависит от возраста начала курения, его продолжительности и количества сигарет, выкуриваемых ежедневно. В литературных источниках много работ посвящено исследованию влияния курения на состояние пародонта. Однако ряд аспектов, в частности состояние свободнорадикального окисления, оставленный без должного внимания, что и будет целью наших дальнейших исследований.

Ключевые слова: табакокурение, полость рта.

\section{V. Shcherba, O. Ya. Lavrin}

I. Horbachevsky Ternopil State Medical University

\section{Smoking: prevalence and impact on organs and tissues of the oral cavity (literature review)}

Summary. Smoking is a global problem of humanity, and its impact on the organs and tissues of the oral cavity is a major health and social problem. Smoking is associated with significantly increased risk of the oral cavity diseases, especially with paradont pathology and cancer. Persons who have extensive experience of smoking, use tobacco products for oral use, except of smoking alcohol abuse belong to risk group of the oral cavity cancer. The severity of periodontal disease depends on the age of onset of smoking, duration of smoking and number of cigaretteswhich are smoked daily. In the literature many papers are devoted to research the impact of smoking on periodontal status. However, a number of aspects, including free radical oxidation state is left without proper attention, which is the aim of our further investigation.

Key words: smoking, oral cavity. 
Широка розповсюдженість тютюнокуріння є глобальною проблемою людства, на вирішення якої спрямоване зусилля багатьох учених i фахівців. Сьогодні у світі налічується близько 1,3 млрд людей, які курять, у країнах СНД біля 29 \% дорослого населення, у країнах Європи-до 28 \%. Велика поширеність куріння серед чоловіків відмічається у Латвіі,, Естонії, Польщі, Молдові, Туреччині, в Україні. Найбільше курців серед чоловіків у Південній Кореї (68 \%), а серед жінок - у Данії (37 \%). Населення України становить 0,85 \% від населення Землі, а 1,5 \% світової тютюнової продукції споживається в Україні. За споживанням цигарок Україна посідає 17 місце серед усіх країн світу. За даними інформаційного центру з проблем алкоголю, куріння і наркотиків в Україні 19 млн осіб курять цигарки, з яких $40 \%$ у віці старше за 15 років (з них 34 \% курять щодня, 6 \% - час від часу). Цей показник $є$ одним із найвищих серед країн Європи. Загалом, тютюнокуріння населенням за останні 10 років збільшилося у п’ять разів [7].

Тютюнокуріння в усьому світі призводить до величезних негативних наслідків. За даними звіту ВОО3, виданого 2013 року, від спричинених тютюном хвороб у світі щорічно помирає близько 6 млн осіб. Якщо не вжити негайних заходів, тютюн вб’є 1 млрд людей протягом цього сторіччя. Викликані тютюном хвороби та смерті серед працездатних людей та інші негативні наслідки тютюнокуріння спричиняють величезні економічні збитки, загальносвітовий обсяг яких становить більше 500 мільярдів доларів на рік. В Україні, за оцінками міжнародних експертів, тільки непрямі щорічні витрати, спричинені тютюнокурінням, сягають 3 млрд доларів США [1].

Куріння набуло характеру епідемії, широко поширеною серед чоловіків, жінок і дітей. Загалом куріння виступає фактором ризику більш ніж 20 хвороб, які становлять майже 75 \% у структурі причин смертності населення. За науковими даними, куріння скорочує тривалість життя на 5 років для 35-річної жінки, яка курить, або 7 років для 35-річного чоловіка-курця [10]. Від наслідків куріння щорічно помирає близько 4 млн жителів планети. Тому в багатьох країнах світу ведеться активна боротьба з ним у рамках проекту Всесвітньої організації охорони здоров’я [3].

Вивчення впливу куріння на стан порожнини рота є великою медико-соціальною проб- лемою, адже ротова порожнина - це перший бар'єр на шляху тютюнового диму в організмі людини. 3 курінням пов'язують істотне підвищення ризику ряду захворювань органів i тканин порожнини рота, перш за все патології парадонта та онкологічних новоутворень порожнини рота [11]. Ще в минулому столітті було встановлено несприятливий вплив тютюну на стан зубощелепної системи. Куріння негативно впливає на стан органів порожнини рота, викликаючи забарвлення зубів, зубних реставрацій, протезів, призводить до розвитку таких захворювань, як лейкоплакія Таппейнера, меланоза курців і т. д. [3, 8, 19].

Крім того, курці частіше стикаються 3 проблемами галітозу (смердючого дихання), утворення специфічного щільного зафарбованого нальоту на зубах і під’ясенного зубного каменя, сухістю в порожнині рота і смаковими інверсіями [11]. За даними C. І. Токмакової, причинами галітозу в курців вважають: 1) смоли, нікотин, продукти згорання тютюну мають власний неприємний запах; 2) при курінні знижується кількість кисню в порожнині рота, що сприяє життєдіяльності анаеробів і катаболізму білків; 3) для курців характерні зміни слизової оболонки: сухість і дегенерація; 4) куріння сприяє розвитку запальних захворювань пародонта та відкладенню зубного каменя [9].

Куріння, будучи найпоширенішою шкідливою звичкою, призводить до впливу на тканини ясен і зубів диму, що містить понад 4000 вельми активних сполук, здатних викликати досить специфічні зміни зубів і тканин порожнини рота: коричнево-жовті відкладення на поверхні зубів і коренів, нікотиновий стоматит, порушення репаративних процесів, збільшення інтенсивності току ясенної рідини в момент куріння [4]. При курінні вплив на організм людини складових тютюнового диму може впливати безпосередньо на слизову оболонку порожнини рота, носа і бронхів, що характеризується високим ступенем проникності, й опосередковано, коли ці речовини після ряду перетворень в організмі курця потрапляють з кров’ю в слинні залози і виділяються зі слиною в порожнину рота. Зміни, що виникають при цьому в ротовій рідині, слизовій оболонці порожнини рота, тканинах пародонта, зубів і слинних залоз можуть бути першими симптомами для діагностики захворювань, зумовлених тютюнокурінням. Однак 
питання про стан тканин порожнини рота у курців все ще залишається спірним і не до кінця вивченим [4].

Руйнівний вплив тютюнокуріння на органи і тканини порожнини рота спочатку має тепловий характер. Температура тютюну, що тліє, становить $30^{\circ} \mathrm{C}$, а під час затяжки вона досягає 90-100 ${ }^{\circ} \mathrm{C}$. Температура тютюнового диму зазвичай складає $40-60{ }^{\circ} \mathrm{C}$ [9]. В даний час куріння є одним із значущих чинників ризику розвитку запальних захворювань пародонта. Патогенез цієї патологї тісно пов'язаний 3 порушенням вільнорадикального окиснення у ротовій рідині. Генерація активних форм кисню і пероксидне окиснення ліпідів зумовлюють стан вільнорадикального окиснення. Вільні радикали спричиняють окисний стрес і можуть пошкоджувати біологічні мембрани [3, 16]. У літературних джерелах багато робіт присвячено дослідженню впливу куріння на стан пародонта. Однак ряд аспектів, зокрема стан вільнорадикального окиснення, залишений без уваги. При підвищенні рівня вільних радикалів у ротовій рідині пошкоджуються тканини пародонта, разом 3 тим, як нестача активних форм кисню сприяє мікробній інвазіі. Тому як збільшення вільних радикалів, так і зменшення їх вмісту відіграє важливу роль у розвитку захворювань пародонта [2]. Для курців характерний високий ступінь генералізації і тяжкості запалення порівняно з некурцями. Ясна у курців фібронізовані й потовщені. Патології пародонта у курців виникають в 2,5-6 разів частіше, ніж у некурців. Тютюнокуріння сприяє розвитку захворювань парадонта за рахунок декількох механізмів. Органи і тканини порожнини рота є місцем первинного контакту організму курця 3 токсинами і канцерогенами, що входять до складу тютюнового диму (більш як 4000 різних токсинів, у тому числі близько 40 канцерогенів та мінімум 12 речовин, які сприяють виникненню раку). Тютюновий дим пригнічує механізми імунного захисту стійке зниження фагоцитарної функції. Вплив нікотину на мікроциркуляторне русло проявляється в порушенні гемодинаміки у м’яких тканинах порожнини рота, зумовлюючи погіршення трофіки ясен і зниження їі резистентності до інфекції. Розвивається атрофія ацинарних відділів малих слинних залоз і виникають інші морфологічні зміни, характерні для прогресуючого хронічного сіалоденіту.
Знижується здатність фібробластів до синтезу колагену, що призводить до руйнування зубоясенного прикріплення і подальшої резорбції альвеолярної кістки $[9,11]$.

У зарубіжній літературі є поодинокі повідомлення про вплив цигаркового диму на мікроциркуляторні розлади, однак цих даних абсолютно недостатньо. Механізми впливу куріння на розвиток захворювань пародонта дуже різноманітні й досліджені далеко не до кінця [23]. При аналізі впливу куріння на загальні показники захворювань пародонта в Сполучених Штатах, було підраховано, що 41,9 \% випадків періодонтиту зумовлені теперішнім курінням і 10,9 \% були пов'язані 3 колишнім курінням. Грунтовний аналіз куріння і болю в ротовій порожнині показали, що курці мають підвищений ризик орального болю, але коли вони припиняють курити, ризик болю значно зменшується. Це зміцнює думку, що уникання або припинення куріння може призвести до значного поліпшення стану здоров’я порожнини рота [13].

I. В. Кочієва та співавт. провели обстеження в 30 добровольців у віці від 20 до 45 років, що зловживають тютюнокурінням. У всіх випадках стаж куріння склав не менше 1 року. Як метод дослідження була використана лазерна доплерівська флоуметрія (ЛАКК-М, ТОВ «Лазма», Росія) для виявлення особливостей мікроциркуляції у тканинах пародонта в осіб, які курять, 3 інтактним пародонтом. Паралельно з лазерною флоуметрією проводили вітальну тканинну оксиметрію, що дозволяло спостерігати зміну сатурації кровотоку киснем. У всіх пацієнтів після впливу було зниження параметра оксиметрії тканин пародонта, який через деякий час відновлювався. У середньому час відновлення становив 15 хв. Зниження оксигенації варіювало від 25 до 60 \% порівняно з вихідним. Після викурювання цигарки у пацієнтів, які курять, в тканинах пародонта відбуваються виражені зміни показників мікроциркуляції. В першу хвилину після куріння відбувається вазодилатація і різке збільшення рівня кровотоку, потім виникає вазоконстрикція і зменшення рівня кровотоку [2].

Ю. О. Солдатова та співав. після проведеного дослідження виявили середні показники інтенсивності карієсу зубів, ступінь захворювань пародонта, стан слизової оболонки порожнини рота і гігієни у пацієнтів відповідно 
до стажу куріння. Середні показники стоматологічного статусу обстежуваних пацієнтів погіршуються зі збільшенням стажу куріння. Якщо при стажі до 5 років гігієна порожнини рота в середньому задовільна, то у людей, які курять більше 15 років, показники помітно погіршуються. Теж спостерігається і за іншими критеріями. Тривалість куріння різко негативно позначається на стані слизової оболонки, що видно з показників індексу РМА, який зі збільшення стажу курця підвищується 3 27 \% (обмежена поширеність запалення) до 58 \% (виражена поширеність запалення). Оцінка стану тканин пародонта також виявила пряму залежність ступеня ураження від тривалості впливу тютюну. Середні показники парадонтального індексу з 0,8 (легкий ступінь ураження пародонта) збільшуються до 4,79 (тяжкий ступінь із вираженою деструкцією кісткової тканини) [8]. Помірні й важкі форми періодонтиту спостерігають у 25,7 \% курців, 20,2 \% колишніх курців і 13,1 \% некурців. Різниця в поширеності періодонтальної хвороби для цих трьох груп статистично достовірна. Поширеність помірного і тяжкого періодонтиту в нинішніх або колишніх курців сигари/ трубки оцінено в 17,6 \% [6]. Мікрофлора порожнини рота в результаті куріння зазнає суттєвих змін. У порожнині рота курця більш високий відсоток патогенних мікроорганізмів, ніж у людини, що не курить [11]. Основний ефект куріння дослідники пов'язують з активацією бактеріальної агресії і посиленням розвитку мікробних бляшок і зубного каменя [23]. Хоча курці мають більше зубного нальоту, ніж некурці, немає жодних підстав вважати, що куріння збільшує швидкість, 3 якою розвивається зубний наліт. Куріння сигарет може привести до зниження окисновідновного потенціалу, і це може призвести до збільшення кількості анаеробних бактерій. Встановлено статистично значуще збільшення частки грампозитивних до грамнегативних бактерій у триденному зубному нальоті курців порівняно $з$ некурцями [12].

Тютюновий дим містить феноли і ціаніди, які можна враховувати до антибактеріальних та токсичних властивостей. Курці мають значно вищі рівні й більш високі ризики зараження бактерією Tannerella forsythensis, ніж некурці. Більш виражений ступінь тяжкості захворювання, спричинений інфікуванням Porphyromonas gingivalis, спостерігався у кур- ців, ніж у некурців [18]. Тим не менш відносний ризик зараження цією бактерією не був вищим у курців.

Порівняно з людьми, які ніколи не курили, курці більш схильні повідомляти про чутливість зубів до гарячого або холодного, зубний біль і біль у порожнині рота за попередній період. Також курцям більш притаманно повідомляти про використання зубних протезів та соціальні обмеження через їхні зуби. Частка респондентів, які повідомили, що здоров’я їх порожнини рота є відмінним/дуже добрим була нижчою серед курців (44\%), ніж ті, хто ніколи не курив (60 \%) [13].

Тютюновий дим може бути причиною пошкодження ясен, призводити до таких захворювань як кровоточивість ясен, гінгівіт, пародонтит за рахунок зменшення рівня вітаміну С і в цілому антиоксидантних властивостей. Курці схильні до втрати зубів у 2,5 раза більше, ніж люди, які ніколи не курили. Колишні курці схильні до втрати в 1,5 раза більше. Навіть ті люди, які кинули курити близько 30 років тому, схильні до втрати зубів більшою мірою. Знаходження в середовищі, де присутні курять, теж позначається на здоров’ї зубів. Люди, які ніколи не курити, в 1,22 раза більш схильні до втрати зубів, якщо протягом 1-5 год в день вони знаходяться у середовищі курців. Ця цифра зростає до 1,37, якщо перебування в середовищі становить більше 6 год на день [5].

Запалення ясен, яке розвивається упродовж декількох фаз, додатково впливаючи на інші частини пародонта, i, нарешті, перетворюючись в періодонтит. Зміни на рівні кровоносних судин є першим проявом запалення ясен (первинне ураження). Капіляри розширюються і кровотік збільшується. На початковій стадії, первинне ураження стає більш вираженим, запальний інфільтрат також збільшується, що клінічно зумовлює збільшення ясен. Це супроводжується змінами клітинної популяції - збільшенням числа лімфоцитів і макрофагів. Розгорнуте ураження виникає як наслідок присутності зубних бляшок, коли деякі з бактерї можуть проникати в тканинини господаря. Периваскулярне накопичення хронічних запальних клітин проявляється на цьому етапі. 3більшення числа клітин в хронічному запальному вмісті супроводжується втратою колагену в ураженій сполучній тканині. Проте на цьому етапі до сих пір немає втрати кісткового або сполучно-тканинного кріплення [17, 22]. 
Куріння давно вважається етіологічним фактором гострого некротичного виразкового гінгівіту (ANUG). R. W. Rowland у своєму дослідженні встановив [20], що тютюнокуріння було причиною ANUG і що зі збільшенням вживання тютюну спостерігалося підвищення частоти виникнення ANUG. У курців швидкість слиновиділення вища, ніж у некурців, а значення $\mathrm{pH}$ зміщене в бік алкалозу. Ознаки ураження малих слинних залоз у курців інтерпретовані як характерні для прогресуючого хронічного атрофічного сіалоаденіту: зменшення кількості активно функціонуючих залоз, зниження ними швидкості секреції, прогресуюча атрофія їх ацинарних відділів, внутрішньочастковий, міжчастковий та перидуктальний склероз, ліпоматоз, ектазія проток з формуванням мікрокіст, вогнищева лімфоплазмоцитарна інфільтрація [9]. Піднебіння курця (синоніми: нікотиновий стоматит, лейкокератоз) зустрічається особливо у важких довгострокових курців трубки, а також курців сигар або сигарет. Піднебіння курця розвивається $з$ його характерними клінічними ознаками: білі, бляшкоподібні зміни на слизовій оболонці піднебіння внаслідок гіперкератозу поєднані $з$ множинними червоними точками, розташованими в центрі невеликих підвищених вузликів, що є розтягненими і запаленими отворами проток малих слинних залоз. Термічні впливи, що діють на місцевому рівні більше, ніж хімічні агенти, несуть відповідальність за виникнення цих змін $[14,15]$.

Злоякісні утворення, захворювання пародонта й ураження порожнини рота - основні проблеми, з якими лікарю-стоматологу доводиться стикатися у своїй практиці. Найбільш важливим напрямком у боротьбі з цими захворюваннями $є$ їх профілактика. Виникненню даних захворювань передує тривала дія хімічних, фізичних, біологічних факторів на слизову оболонку порожнини рота, зокрема тютюнокуріння $є$ одним із факторів, що веде до захворювань порожнини рота. Рак слизової оболонки порожнини рота у більшості випадків пов'язаний $з$ тютюновим димом. Надмірний прийом алкоголю діє синергічно 3 тютюновим димом, що значно посилює ризик виникнення раку. Особи, що викурюють більше 50 пачок на рік мають в 77,5 раза більший ризик розвитку раку слизової порожнини рота, ніж некурці. Більшість дослідників вважає основним механізмом індукції онкологічних захворювань як пряму канцерогенну дію сигаретного диму на шкіру, так і системний вплив, оскільки нікотин та інші компоненти тютюну виявленів різних рідинахітканинахорганізму. Рак слизової порожнини рота найчастіше виникає у ділянці вуздечки язика, в поглибленні за останнім нижнім корінним зубом, а також у місці переходу слизової на щічну поверхню і тверде піднебіння. Спочатку ракова пухлина виглядає як папіломатозне або грибоподібне утворення на ніжці або широкій основі. 3 плином часу може покритися виразками, в основі їі з'явиться інфільтрація, при екзофітній формі на початку захворювання утворюється невеликий інфільтрат, розташований під слизовою оболонкою. Виразкова форма починається і перебігає у вигляді ерозії, тріщини, що з'являється найчастіше на тлі передракового захворювання. Приєднання інфільтрації тканин говорить про змішану форму раку, найбільш характерною для даної локалізації [5].

Лейкоплакія являє собою зроговіння слизової оболонки порожнини рота або червоної облямівки губ, що супроводжується запаленням, яке виникає, як правило, у відповідь на хронічне екзогенне подразнювання. Певну роль у патогенезі лейкоплакії відіграють ендогенні фактори, але більш важливі зовнішні (механічні, термічні, хімічні) подразнювальні чинники, особливо при їх поєднанні. Першорядне значення має вплив гарячого тютюнового диму, який викликає в епітелії збільшення ядер клітин, розмірів клітин і раннє зроговіння. При локалізації лейкоплакії на червоній облямівці губ велике значення в їі виникненні надається хронічній травмі мундштуком, цигаркою або сигаретою (тиск), систематичного припікання губи при докурюванні сигарети до кінця, а також несприятливих метеорологічних умов, перш за все інсоляції. Дослідження показують, що від 72 до 99 \% хворих на лейкоплакію зловживали тютюном [5]. Лейкоплакія курців Тапейнера. Це захворювання є різновидом лейкоплакії слизової оболонки порожнини рота. Виникає воно на слизовій оболонці твердого піднебіння, причому виключно у курців. У літературі можна зустріти інші назви цього патологічного процесу: нікотиновий лейкокератоз піднебіння, нікотиновий стоматит, піднебіння курця. Слизова оболонка твердого піднебіння, 
а іноді й примикаючого до неї відділу м'якого піднебіння, виглядає злегка ороговілою, сірувато-білою, часто складчастою. На цьому тлі добре стають помітні червоні точки - зяючі гирла вивідних проток дрібних слинних залоз. При різко вираженому процесі ці червоні точки розташовуються на верхівці невеликих вузликів напівшароподібної форми. Це захворювання особливо часто зустрічається у курців, які курять багато, а також у людей, що курять трубки або сигари. Незважаючи на назву хвороби, основною причиною захворювання $є$ вплив смол і високої температури, а не нікотину. На відміну від інших форм лейкоплакії ця хвороба швидко проходить, протягом приблизно 2 тижнів після припинення куріння. Теоретично можливе злоякісне переродження лейкоплакії курців Тапейнера, втім, як і будь-якого процесу, що супроводжується значною гіперплазією епітелію, що виникає під впливом куріння [5].

Меланоз курця є дифузною, неправильної форми, коричневою пігментацією слизової оболонки порожнини рота 3 переважанням кератинізації слизової оболонки, але може бути присутнім на слизовій оболонці щік, дна порожнини рота і м'якого піднебіння. Куріння тютюну як відомо, стимулює меланоцити порожнини рота, що призводить до збільшення продукції меланіну особливо в темношкірих

\section{Список літератури}

1. Контроль над тютюном в Україні. Другий Національний звіт. - К. : МОЗ України, ДУ«Український інститут стратегічних досліджень МО3 України», 2014. -128 c.

2. Кочиева И. В. Влияние табакокурения на микроциркуляцию в тканях парадонта / И. В. Кочиева, С. Н. Мкртчян, С. К. Хетагуров // Журнал научных статей «Здоровье и образование в XXI веке». - 2015. T. 17, №. 1. - Р. 57-58.

3. Лечение воспалительных заболеваний пародонта у курящих лиц молодого возраста / Л. П. Герасимова, М. М. Аль-Табиб, М. Ф. Кабирова та ін. // Фундаментальные исследования. - 2014. - № 7. - С. 463-467.

4. Методы профилактики хронического пародонтита при никотиновой зависимости в молодом возрасте с точки зрения гемодинамических нарушений в пародонте / О. О. Янушевич, А. Л. Верткин, А. В. Наумов, В. А. Вышиванюк // Современная стоматология. - 2012. - № 3(62). - С. 41-47.

5. Норина А. Л. Роль табака в возникновении рака, заболеваний пародонта и поражений полости рта (обзор литературы) / А. Л. Норина, Д. Е. Мильчаков // Международный научно-исследовательский журнал. - 2014. - № 4 (23). - С. 15-19. етнічних груп. Недавнє дослідження, проведене серед населення Нігерії, показало, що курці мали значно вищу поширеність пігментованих ділянок на слизових оболонках порожнини рота, ніж у некурців, а кількість пігментованих ділянок збільшилася зі ступенем і тривалістю куріння $[21,15]$. Меланоз курців не класифікується як передраковий стан або попередник виразкування, і є зворотним після припинення тютюнокуріння.

Таким чином, вплив тютюнокуріння на стан порожнини рота є великою медико-соціальною проблемою. 3 курінням пов’язують істотне підвищення ризику ряду захворювань органів і тканин порожнини рота, перш за все патології парадонта та онкологічних новоутворень в порожнині рота. До групи ризику виникнення раку порожнини рота належать особи, які мають великий стаж куріння, використовують тютюнові продукти для перорального застосування, крім куріння зловживають алкоголем. Тяжкість захворювань пародонта прямо залежить від віку початку куріння, тривалості куріння та кількості цигарок, які викурюються щодня. У літературних джерелах багато робіт присвячено дослідженню впливу куріння на стан пародонта. Однак ряд аспектів, зокрема стан вільнорадикального окиснення, залишений без належної уваги, що і буде метою наших подальших досліджень.

6. Орехова Л. Ю. Состояние тканей пародонта у курящих пациентов с хронической обструктивной болезнью легких / Л. Ю. Орехова, Н. Л. Шапорова, Е. В. Косова // Пародонтология. - 2008. - № 1. - С. 12-17. 7. Пікас О. Б. Про стан куріння цигарок у сучасних умовах, його вплив на виникнення захворювань в організмі людини / О. Б. Пікас // Буковинський медичний вісник. - 2015. - Т. 19, № 4 (76). - С. 227-230.

8. Солдатова Ю. О. Влияние длительности курения на стоматологический статус пациента / Ю. О. Солдатова, Г. Ш. Зубаирова, А. И. Булгакова // Международный журнал экспериментального образования. - 2012. - № 6. - С. 47-48.

9. Токмакова С. И. Влияние табакокурения на слизистую оболочку полости рта / С. И. Токмакова, Ю. В. Луницина // Забайкальский медицинский вестник. - 2012. - № 1. - С. 124-130.

10. Тяжка О. В. Пасивне куріння дітей раннього віку / О. В. Тяжка, Т. О. Ванханова // Медицина транспорту України. - 2012. - № 1. - С. 93-99.

11. Шепилев В. В. Профилактика заболеваний полости рта, связанных с курением / В. В. Шепилев, С. М. Ворожбит, Т. В. Камина // Стоматолог. - 2007. № 9. - C. 20-22. 
12. Association between cigarette smoking, bacterial pathogens, and periodontal status. / J. L. Stoltenberg, J. B. Osborn, B. L. Pihlstrom [et al.] // J. Perio. 1993. - Vol. 64. - P. 1225-1230.

13. Millar W. J. Smoking and Oral Health Status / W. J. Millar, D. Locker // JCDA. - 2007. - Vol. 73, No. 2. - P. 155-155.

14.MirbodS.M.Tobacco-associatedlesionsoftheoralcavity: Part I. Nonmalignant lesions / S. M. Mirbod, S. I. Ahing // J. Can. Dent. Assoc. 2000 - Vol. 665. - P. 252-256.

15. Oralhealthrisks of tobaccouseand effects of cessation/ S. Warnakulasuriya, T. Dietrich, M. M. Bornstein [et al.] // International Dental Journal. -2010. - No. 60. - P. 7-30. 16. Panjamurthy K. Lipid peroxidation and antioxidant status in patients with periodontitis / K. Panjamurthy, S. Manoharan, C. R. Ramachandran // Cell Mol. Biol. Lett. 2005. -Vol. 10, No. 2. - P. 255-264.

17. Pejcic A. Histological Examination of Gingiva Treated with Low-level Laser in Periodontal therapy / A. Pejcic, V. Zivkovic // J. Oral Laser Appl. - 2007. - Vol. 7. - P. 37-43.
18. Possible potentiation of toxins from Prevotella intermedia, Prevotella nigrescens, and Porphyromonas gingivalis by nicotine / N. M. Sayers, J. A. James, D. B. Drucker, A. S. Blinkhorn // J. Perio. - 1999. - Vol. 70. - P. 1269.

19. Reibel J. Tobacco and oral deseases / J. Reibel // Med. Princ. Pract. - 2003. - Vol. 12, Suppl 1. - P. 22-32.

20. Rowland R.W. Necrotizing ulcerative gingivitis / R. W. Rowland // Ann. Perio. - 1999. - Vol. 4. - P. 65-73. 21. Smokers' melanosis in a Nigerian population: a preliminary study / Nwhator S. O., Winfunke-Savage K., Ayanbadejo P. [et al.] // J. Contemp Dent Pract. - 2007. Vol. 85. - P. 68-75.

22. Smoking and periodontal disease a review / A.Pejčić, R. Obradović, L. Kesić, D. Kojović // Facta universitatis. Series: Medicine and Biology. - 2007. Vol.14, No. 2. - P. 53-59.

23. The effect of smoking on periodontal treatment response: a review of clinical evidence / L. Haesman, F. Stacey, P. M. Preshaw [et al.] // Journal of Clinical Periodontology. - 2006. - Vol. 33. - P. 241-253.

Отримано 02.06.16 